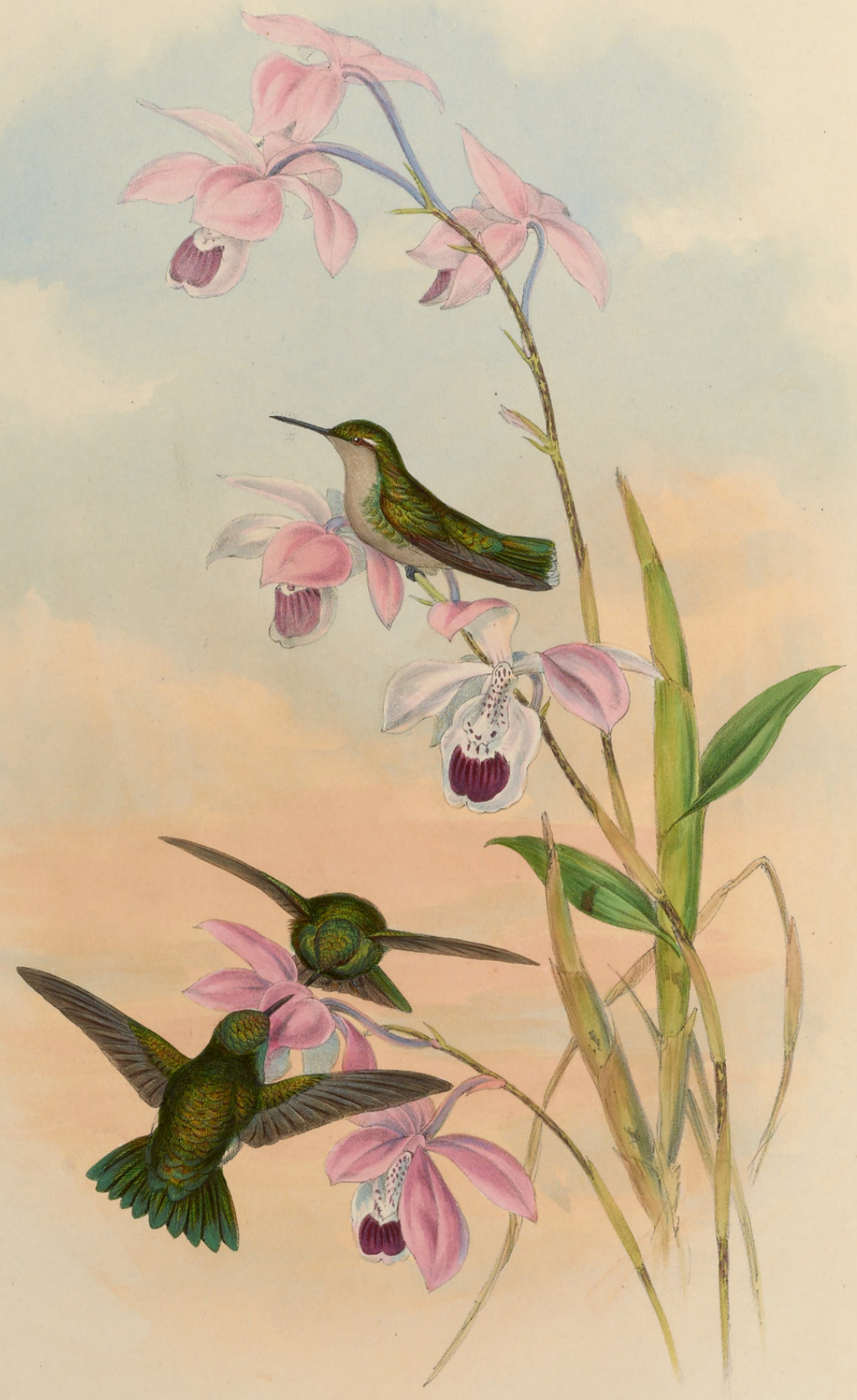




\title{
CHLOROSTILBON ALICIAE.
}

\author{
Alice's Emerald. \\ Trochilus Alice, Bourc. et Muls. Rev. Zool. 1848, p. 274.-Gray and Mitch. Gen. of Birds, \\ vol. iii., App. p. $30 a$, App. to p. 103. \\ Smaragdites Alice, Reichenb. Auf. der Col., p. 7. \\ Chlorostilbon alicia, Bonap. Rev. et Mag. de Zool. 1854, p. 255.
}

Tне Chlorostilbon Alicice is a pretty little species, inhabiting the Caraccas and the high lands of Columbia; collections sent from Bogota always contain examples. It is easily distinguished from every other member of the genus by its greenish-bronzy hue and the shortness of its tail-feathers; it is also conspicuous for the rich glittering golden green of the crown, throat, breast, and under surface of the body; both the upper and under surfaces of the tail, too, are bronze, with an intermingling of purple.

The sexes offer a more marked difference than usual, the female being entirely destitute of the glittering green feathers of the under surface; besides which, she has a larger tail, the three outer feathers of which are black in the centre, with grey tips. We have striking proofs that the bird so marked is the true female of this species; for the young males, at a certain age, are dressed in a particoloured plumage, portions of which are seen in both sexes. I have one young male in which the breast is grey, like that of the female, except that it is here and there spangled with golden green; in this example the three outer tail-feathers are tipped with grey, but the centre ones are green, and not black, as in the female ; the female, too, is a somewhat larger bird, and has a longer bill than the male.

The male has the crown of the head and breast rich shining green; all the upper surface, wing-coverts, upper tail-coverts, abdomen, and under tail-coverts rich bronzy green; wings purplish brown ; tail, both on the upper and the under surface, shining dark purplish green; bill black; feet dark brown.

A young male in my collection is bronzy green above, and greyish white, speckled or spangled with rich shining green, beneath; wings purplish brown; centre tail-feathers green; lateral feathers green at the base, then bluish black, and tipped with white; under tail-coverts buffy grey.

The female has the upper surface bronzy green, passing into pure green on the upper tail-coverts; under surface greyish white; central tail-feathers green; the lateral feathers green at the base, then black, and lastly tipped with grey, which increases in extent as the feathers recede from the centre.

The Plate represents two males and a female of the size of life. The plant is the Barkeria elegans. 


\section{$2 \mathrm{BHL}$ Biodiversity Heritage Library}

Gould, John. 1861. "Chlorostilbon alieiæ, Alice's Emerald. [PI. 357]." A monograph of the Trochilidae, or family of humming-birds 5, https://doi.org/10.5962/p.317166.

View This Item Online: https://www.biodiversitylibrary.org/item/108806

DOI: https://doi.org/10.5962/p.317166

Permalink: https://www.biodiversitylibrary.org/partpdf/317166

\section{Holding Institution}

Smithsonian Libraries

\section{Sponsored by}

Smithsonian Institution Libraries

\section{Copyright \& Reuse}

Copyright Status: NOT_IN_COPYRIGHT

This document was created from content at the Biodiversity Heritage Library, the world's largest open access digital library for biodiversity literature and archives. Visit BHL at https://www.biodiversitylibrary.org. 